\title{
GREAT POWERS AND THE STRAITS: FROM LAUSANNE TO MONTREUX
}

Since the beginning of the 19th century, the territories of the Ottoman Empire have been a bone of contention for the Great Powers. The so-called "sick man of Europe" had occupied the thoughts of numerous statesmen in Europe. The Balkans attracted the Russians and Austrians while Egypt and the Levant had always whetted British and French appetites. But the rifts existing among those powers and the diplomatic maneuvers of the Porte saved the Empire from annihilation. If the Porte had any capacity to manipulate the outcome of events, it was indeed, as Ahmet Şükrü Esmer (1947) aptly claimed, grounded on the question of the Straits.

The Straits were the main barrier before Russian encroachment into the Eastern Mediterranean and thus into the Middle East. Despite their relative distance from the Straits, the British had suspected that the Russians would expand at their expense in the Middle East. They decided to prevent a major rival from getting a foothold in the region. This policy had rather coincided with Turkish interests until the end of the century when a new threat, Germany, superseded Russia in the eyes of the British. Britain became what Mathisen called (1971: 140) an "acquisitive friend of the Turks". It obtained Cyprus at the Berlin Conference in 1878, and occupied Egypt in 1882. British interests clashed with Turkish strategic interests until the mid-1930s.

For several years after the First World War, neither the Soviet Union, nor Germany were able to gather sufficient strength to threaten British interests. When that happened, Britain began to adopt a more conciliatory attitude towards Turkey. This was first demonstrated in the drafting of the Montreux Convention and continued through the 1940s. 


\section{Towards Lausanne:}

So long as the Ottomans had ruled the coasts of the Black Sea, the way they exercised control over the Straits was not a matter of interest to the other powers. However, when Russia expanded to the Black Sea and sought to acquire a privileged position at the Straits, this alarmed Great Britain which already had vested interests in the Mediterranean. Anglo-Russian relations had been deeply affected by a persistent conflict of views on the régime of the Straits, and the Porte tried to utilize this conflict.

The Ottoman Sultans forbade all foreign shipping through the Straits until the Treaty of Küçük Kaynarca (Kaynarjai) in 1774, which conceded to Russian merchant shipping the right of free navigation in both the Black Sea and the Straits. ${ }^{1}$ Article XI of the Treaty stipulated the right of free passage of the Russian merchant ships (for details of the Text of the Treaty see Hurewitz, 1956: 54-61 and Israel, 1967: 913).

But the concessions for merchant shipping had not satisfied Russian ambitions. Since then, the Russian objective has always been to secure free passage for the Russian fleet between the Black Sea and the Mediterranean without conceding the right of entry into the Black Sea to the warships of the non-riparian states. This objective gained its utmost impetus after the defeat of Russia by Japan in 1905. The inability of the Russian Government to send their Black Sea Fleet into Far Eastern seas during the war with Japan had increased the intensity of this desire. Other developments, such as rivalry with Austria for influence over the states of the Balkan peninsula, and the growth of German influence over the Porte, alarmed the Russians.

For all these reasons the Russian Government vigorously tried to revise, from 1906 onwards, the régime of the Straits. The Russians hoped to change the parts of the Straits régime concerning the passage of warships, and the British attitude toward this issue became crucial for the Russians. Apart from a few exceptions, the passage of warships through the Straits had at all times been prohibited by Turkey. ${ }^{2}$

The British attitude, on the other hand, had undergone a striking reversal at the later part of the 19th century. The advantages of excluding the

${ }^{1}$ Long before the Treaty, Peter the Great had appealed to the Porte for free commerical navigational rights on the Black Sea. After the refusal Peter tried force to achieve his ends. But the Russians were defeated by Baltac1 Mehmet Pasha and even forced to cede territory to the Ottomans with the Treaty of Pruth in 1711. See Kunt (1990: 49-50).

${ }^{2}$ For a short overview of the Straits issue and of these exceptions see Uçarol (1992: 165-202). 
Russian Fleet from the Mediterranean had become less substantial when compared with the disadvantages of British inability to send warships into the Black Sea. As early as 1878 , Lord Salisbury had appreciated the problem. ${ }^{3}$ He wrote that "the exclusion of Russia from the Mediterranean is not so great a gain to us as the loss resulting from our exclusion from the Black Sea, because we are much the strongest as a naval Power" (F.O. 371/67286/ R9068).

The reasons for a reversal of the British policy were multiplied thereafter. The occupation of Cyprus in 1878 and then of Egypt with its Suez Canal in 1882 greatly diminished the dangers from a possible Russian sortie into the Eastern Mediterranean. Since the British were physically controlling Mediterranean waters, they saw little reason to protect the shaky Ottoman Empire. Moreover, the tensions along the frontiers of the Russian and the British Empires in Central Asia increased the desirability of being able to threaten Russia in the Black Sea. The advantages of being able to deploy a superior sea power into the Black Sea had made itself felt during the Crimean War.

The strategic consequences of opening the Straits to Russian warships had already been considered by the British when the Russian Foreign Minister A.P. Izvolsky asked Edward Grey for the revision of the Straits régime in 1908. The British Committee of Imperial Defence was of the opinion about the strategic effects of opening the Straits to Russian fleet in 1903 that "while Russia would no doubt obtain certain naval advantages from the change it would not fundamentally alter the present strategic position in the Mediterranean" (F.O. 371/ 67286/ R9068).

Another concrete development was the April 1907 agreement between Russia and Britain. After the defeat by Japan in 1905, Russia had turned away from plans of expansion in the Far East. They decided to refrain from threatening British interests in China. By this time, the British had begun to consider the German naval program as a serious threat. Under these circumstances, it seemed reasonable for both Britain and Russia to reach a setlement on outstanding questions arising out of their imperial rivalries. The agreement signed in April 1907 provided fot the neutralisation of Tibet. On the other hand, the Russians recognized the British interests in Afghanistan, and Persia was divided into Russian and British spheres of influence. Thus, the immediate causes of friction between Britain and Russia were removed (see Joll, 1976: 100).

Izvolsky suggested in 1908 that in time of war when Turkey was neutral, she should observe her neutrality by giving equal facilities for

\footnotetext{
${ }^{3}$ For the change of the British policy see Tukin (1947: 329-334), Vali
} (1972: 25). 
passage through the Straits to all belligerents. To the dismay of Turkey this proposal was welcomed in the British Foreign Office. However, negotiations were not opened for fear of reaction from British public opinion (see FO 371/67286A/R9068).

Within the six years prior to the First World War, Russian attention came to be focused on more radical methods of obtaining access to the Mediterranean. When a general war became imminent, the Tsar's principal advisers held a conference in 1914 to recommend that they should be prepared both militarily and diplomatically for the Russian occupation of the Straits in the event of war. When in February 1915 Russia's Western Allies attacked the Dardanelles, she presented her claims in the spring of the same year.

In a memorandum presented to the British and French Ambassadors at Petrograd, Tsar Nicholas II demanded the definite solution of "the time honoured aspirations of Russia" with respect to "Constantinople". It was further stated that

"Every solution will be inadequate and precarious if the city of Constantinople, the western bank of the Bosphorus, of the Sea of Marmara and the Dardanelles, as well as southern Thrace to the Enez-Midye line, should henceforth not be incorporated into the Russian Empire.

"Similarly, and by strategic necessity, that part of the Asiatic shore that lies between the Boshphorus, the Sakarya River, and a point to be determined on the Gulf of tzmit, and the island of the Sea of Marmara, the Imbros Islands, and the Tenedos Island must be incorporated into the Empire."4

The British and the French governments agreed to the annexation by Russia of the entire region in March 1915. However, "in the view of the fact that Constantinople will always remain a trade entrepot for South-Eastern Europe and Asia Minor", the British government asked from the Russians "a free port for goods in transit to and from non-Russian territory" as well as freedom of passage for merchant ships passing through the Straits (Vali, 1972: 179). With the realization of this agreement, Russia expected to become a Mediterranean Power. As admitted by the British in their memorandum to the Russian Government, this was a complete reversal of the traditional British policy. Nevertheless, it was repudiated after the 1917 Bolshevik Revolution by the new Soviet Government at the Treaty of BrestLitovsk.

${ }^{4}$ For the texts of the correspondence between the Russians, French, and British see Hurewitz, Vol II (1956: 7-11). 


\section{The Lausanne Treaty and the Straits:}

At the end of the First World War, the victorious powers imposed the terms of the Sèvres Treaty on the Porte after the US decision to reject a mandate over the Straits. ${ }^{5}$ According to the related articles of the treaty, the Straits area was to be placed under the control of the Commission of the Straits. The Commission would be composed of the representatives of the Great Powers and Greece, Rumania, Bulgaria, and Turkey. But, with the recovery of Turkish power in Anatolia, the dictated peace treaty became inoperative within two years.

In 1922 the negotiations opened on a more equal footing at Lausanne. Turkey's position at the Conference was greatly improved. Besides her own military and political revival, she had also obtained the support of her traditional enemy with the reappearance on the diplomatic scene of a delegation from the Russian Soviet Republic at Lausanne. ${ }^{6}$ The Soviet and Turkish delegates simultaneously resisted the Western Powers and objected to the policy of demilitarization and internationalization of the Straits. The Russian Government feared that this would make possible a repetition of the events of 1918-20, when the Black Sea ports had been bombarded and occupied by Allied forces. They also anticipated that the opening of the Straits would involve expensive military and naval precautions in the Black Sea and in the event of war the Southern Russian divisions might be tied down (FO 371/ 67286A/ R9068). The Turkish representatives, led by Ismet Pasha, had other more immediate interests and, despite their resentment, they could not push the issue further. ${ }^{7}$ The sessions of the Conference devoted to

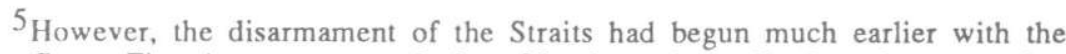
Cease Fire Agreement reached at Moudros. Accordingly, mine sweeping operations had begun on 7 November 1918 and two days after the British had landed their first troops since 1915 to Seddülbahir and Kumkale. The command of 273 cannons, 11 mining positions, 403 mines, 2 submarine nets, 1 torpedo and together with some other instruments was left to the British authorities. For a detailed account of the Straits following the Cease Fire see Bıyıkoğlu (1962: 107-127).

${ }^{6} \mathrm{At}$ the time of the convening of the Lausanne Conference the Western states had not yet recognized the Bolshevik régime in Russia. Therefore, Soviet Russia was not asked to take part in the entire conference. Despite Chicherin's announcement that his government would not take part in the Lausanne Conference until Russia was seated in all sessions, Moscow had later decided to participate in the negotiations to the Straits. Ostensibly, Chicherin only represented Russia, but in reality Chicherin spoke for the entire delegation, including Ukraine and Georgia. For the Lausanne Conference see Howard (1974); Oke (1983); OTDP (1987).

${ }^{7}$ 1smet Inönü in his "Memoirs" gives some account of discussions between Chicherin and himself. He notes that Chicherin was pushing Turkey towards 
the Straits question became a duel between Lord Curzon and Chicherin. Chicherin demanded that the passage of military vessels through the Straits be prohibited at all times. But he noted that "he was willing to compromise on one point and to allow naval vessels through the Straits for missions of mercy" (Crowe, 1973: 28). ${ }^{8}$ He further demanded the restoration of full Turkish sovereignty over the Bosphorus and the Dardanelles with an unrestricted right to fortify their shores.

Finally, the British view prevailed. Article 1 of the Straits Convention of the 24 July 1923 enacted "the principle of freedom of transit and of navigation, by sea and by air, in time of peace as in time of war in the Straits of the Dardanelles, and the Sea of Marmara and the Bosphorus" (Vali, 1972: 184). Article 4 stipulated that the shores of the Bosphorus and the Dardanelles as well as the contiguous islands in the Aegean, including Samothrace, Lemnos, Tenedos, and the Rabbit Islands and all the islands in Marmara, with the exception of Emir Ali Adası, would be demilitarised.

The principles of the Convention were to be implemented by the Straits Commission which would be composed of the representatives of Turkey, France, Great Britain, Italy, Japan, Bulgaria, Greece, Romania, and the Serb-Croat-Slovene State and Soviet Russia. Military security was guaranteed by the High Contracting Parties. Any aggression would be met "by all means that the Council of the League of Nations may decide for this purpose" (Article 18). But the Convention satisfied neither Turkish nor Russian demands. The guarantees given to Turkey by the "High Contracting Parties" would prove to be useless in the years to come. The Turks had lost their strategic advantage against future hostilities. Moreover, they had lost their most important asset.

The concession given to the Soviets with respect to ingress rights to nonlittoral powers to the Black Sea, was also of little practical value in the event of a hostile coalition of two or more powers. It was stipulated in the Convention that the maximum force which any power allowed to send into the Black Sea in time of peace was not to be greater than that of the most powerful navy of the Black Sea powers. In reality, the effects of this concession was further reduced by the stipulation that in "time of war", when Turkey is neutral, it should not be applied in such a way as to prejudice the belligerent rights of any nonriverian state (Article 2b). Moreover, the Soviets had at that time no important naval force in the Black Sea. They had no

a military confrontation with the British on the question of the Straits. See (Inönü, 1987: 77). For a short overview of the discussions between Lord Curzon and 1smet Pasha see Karacan (1943: 108-115).

${ }^{8}$ For the discussions in Lausanne see also Howard (1966: 285-290); Vali (1972: 29); Gürün (1991: 82-102). 
intention of building one under the current economic conditions of the Soviet Union. Routh (1937: 597) claimed that "they no doubt thought also of the new possibility of air attack". Therefore, Chicherin had signed the Convention under protest and it was never ratified by the Soviet Union.

The Soviet Union occasionally reminded the international community that they had not yet reconciled themselves to the Lausanne Convention. During the Rome Naval Conference in April 1924, for instance, the Soviet delegate claimed a maximum of 400,000 tons for the total tonnage of Soviet capital ships against the British proposal of 110,000 tons, unless the Black Sea and the Baltic Sea were closed to the nonlittoral powers. From these and similar acts, if not from direct diplomatic contacts, the Turkish authorities knew that whenever they were to demand revision they would obtain Soviet support.

But convincing Britain was to take some time, not only because of their fear of losing their strategic advantage in the Straits, but also because of their anxiety to avoid dividing Europe into two camps. It was only in January 1936 that the British Foreign Office began to consider the benefits of close alliance with Turkey. In April 1936 the time was ripe for revision. The British were trying to reestablish their position in the Levant, and the Germans and Italians had already proved their aggressive intentions. British interests had once more coincided with Turkish ones.

\section{Montreux Convention:}

In a note sent to the signatories of the Lausanne Straits Convention on 11 April 1936, Turkey demanded the revision of the Convention due to the changes in the general situation in Europe. ${ }^{9}$ Among these changes, the failure of disarmament attempts, the inadequacy, of collective guarantees against a powerful aggressor, and the impossibility of an additional four power guarantee as envisaged by the Convention were noted. ${ }^{10}$ It was further stated that the Straits Convention mentioned only a state of peace and a state of war. But it did not "provide for the contingency of a special or general threat of war or enable Turkey in such a case to provide for her legitimate defence". Accordingly, Turkey demanded the militarization and the fortification of the Straits. It was stated that Turkey "is prepared to enter into negotiations with a view to arriving in the near future at the conclusion of agreements for regulation of the régime of the Straits under the condition of security..." (Vali, pp. 195-199).

\footnotetext{
${ }^{9}$ The original copy of the note can be found at FO 371/ 20073/ E1973.

${ }^{10}$ The fortification of the island of Leros in the Dodecanese had showed clearly to the Turkish Government that the value of the four power guarantee of security had been dangerously eroded with the aggressive Italian policy. See DBFP (Second Series, Vol. XVI, p. 657).
} 
The Turkish note made specific reference to the demilitarization aspects of the Convention. The clauses relating to ingress and egress rights of the Powers were not touched. Tevfik Rüştü Aras, the Turkish Foreign Minister, had even assured Sir Percy Loraine, the British Ambassador to Ankara, on April 10, that the proposed régime would "retain intact" the parts of the Convention that were not concerned with the demilitarised zones (see FO 371/ 20073/ E2024).

The nature and the timing of the note were considered to be perfect by several observers (Armaoğlu, 1984; Crowe, 1973; De Luca, 1973; Routh, 1937). It came only a few weeks after the major German revisions of the post World War I régime. On March 7 Hitler had sent his troops into the demilitarized zones of the Rhineland. It was a violation of the Versailles Treaty as well as the Locarno agreements which Germany had made voluntarily. Moreover, the Italians had been trying to invade Abyssinia since 3 October 1935, and the League of Nations was unable to impose even effective economic sanctions on Italy. Turkey under these circumstances acted quickly to secure the diplomatic advantage.

\section{Powers:}

4. The Turkish Diplomatic Offensive and the Great

However, the diplomatic offensive had begun much earlier. On 24 March 1933, the Turkish Government informed Britain about their intent to raise the question of the remilitarization of the Straits during the forthcoming discussions on disarmament in Geneva. The British Government vigorously rejected the proposed revision on legal grounds. ${ }^{11}$ However, bchind Britain's refusal there were deep strategic and political considerations. The Admiralty feared that refortification of the Straits would jeopardise British naval operations in the Straits and Black Sea if any operation against the Soviets would be necessary. It would also render Turkey less susceptible to coercion and freer to move either closer or further away from Great Britain. It was considered that "'such pressure would be less likely to be effective on Turkey if the Straits were still demilitarised" (FO 371/ 16986/ E2464). The Foreign Office had also feared the possible consequences of the unilateral denunciation

${ }^{11}$ As De Luca explained, Turkey initially constructed its arguments upon the provisions contained in Article 96 of the British Draft to be discussed in the Geneva Disarmament Conference. Britain claimed that Article 96 referred only to arms and armed forces of the former enemy countries. Since the related articles of the Lausanne Convention did not limit the armed forces of Turkey, this article could not be used by Turkey. Besides, the Lausanne Convention could not be regarded as having been imposed on a defeated adversary. Moreover, it did not contain any penal clauses. See De Luca (1973: 23-24). 
of the Lausanne Convention by Turkey. As Sir Orme Sergant of the Foreign Office concluded, the Turkish proposal should have to be resisted "at once and most strenuously, for, if not, we shall get ourselves at once into a frightful mess" (FO 371/ 16986/ E1575).

Despite the British fears and objections, the Turkish Foreign Minister brought up the issue on 23 May 1933, at the forty-seventh meeting of the Gencral Disarmament Conference in Geneva (De Luca, p. 25). As expected, the Russian delegate supported the Turkish position. But the Soviet support was not enough to obtain the necessary backing from the Conference. The proposal was opposed by the British delegate, Sir John Simon, and the French representative "who expressed the sentiment that proposals for treaty revision were out of place at a Disarmament Conference" (Routh, 1937: $601)$. The diplomatic offensive nevertheless continued, and Turkey continued to refresh the memories of the international community. The question was raised, for instance, in the course of the bilateral Greco-Turkish negotiations in Rome in July 1933.

In 1933, rumours were also heard in the diplomatic circles about the joint attempt of Turkey and the Soviet Union for the revision of the Lausanne Convention. Foundation for these rumours was based on the Bessarabian question. It was thought that in the case of any future armed hostilitics between Romania and the Soviet Union over Bessarabia, Turkey would be able to close the Straits after the proposed revision of the Convention. The Italian Ambassador in Ankara argued that all these matters would be arranged with the conclusion of a Black Sea Pact between Turkey and the Soviet Union (Crowe, 1973: 36). Besides rumours, German intelligence had also been told by some informers that Ismet Pasha, when he was in Moscow in 1933, had been asked by the Soviets to sign a mutual defense pact.

Rumours, diplomatic offensives, and the possibility of a Black Sea defense treaty between Turkey and the Soviet Union, alarmed Britain. When a top ranking Sovict delegation came to Ankara for the 10th aniversary of the Turkish Republic, the British and the Americans suspected that they could have only come for signing an important defense treaty. Suspicions grew further when it was learned that the group had toured the military zones of Izmir and the Straits. They were even more annoyed to learn from a leak in the Sovict Embassy in Ankara that the Soviets had supplied 100 electric mines to the Turks. They also heard rumours that the Soviet Government had promised the delivery of 900 more mines in the near future (see Crowe, p. 38). These and similar rumors led the American Ambassador in Ankara, Robert Skinner, on 6 November 1933, to conclude that an understanding 
between Turkey and the Soviet Union on the Straits question must have been reached. ${ }^{12}$

In February 1934, Turkey began to play her Balkan card. Following the signature of the Pact of Mutual Guarantee between Rumania, Yugoslavia, Greece, and Turkey at Athens on February 9, 1934, the Turkish Minister of Foreign Affairs told Sir Percy Loraine, the British Ambassador in Ankara, that "uppermost in Turkish minds respecting the newly signed Balkan Pact was the question of the Straits". Aras, during the same conversation on 19 February 1934, had also mentioned "the idea which had been in his head for sometime past of some kind of regional non-aggression pact, presumably multilateral, embracing Afghanistan, Persia, Iraq, USSR, Turkey, and Great Britain" (DBFP, Second Series, Vol. VII, pp. 656-657).

After Mussolini's famous speech outlining the historical goals of Italy as lying in Asia and Africa on 8 March 1934, Turkey pressed harder. The Turkish authorities began to imply that they could take unilateral action. According to Aras, the Turkish anxiety regarding its security was related to the attitude of Sofia which had undertaken an illegal armament programme with Italian connivance (De Luca, p. 31). Mussolini's speech came also as a rude reminder that, in spite of the Italiano-Turkish Pact signed in 1928 and renewed in 1932, Italy had not abandoned its ambitions in Anatolia. Turkey had not yet forgotten Mussolini's threat of invasion of Anatolia if Turkey went to war over the Mosul dispute in December 1925 (Routh, 1937: 601). The fear of Italy acting through Bulgaria and Italian fortifications in the Dodecanese Islands, especially in the island of Leros, desperately led Turkey to draw the attention of the Great Powers to the Straits issue once again on 17 April 1935. At the occasion of the debate over Pierre Laval's proposal to invoke sanctions against the illegal armament of Germany, Aras addressed the Council of the League of Nations.

Aras denounced the Lausanne Convention as discriminatory and added that certain changes were needed for the revision of the military provisions. Aras in his speech made clear to the participants that "should there be any changes in the situation fixed by existing treaties, Turkey would feel obliged, having regard to her security and to the principle of equality, to modify the régime of the Straits" (Routh, p. 602). Litvinov supported the proposal but at the end the Straits issue was only raised at the Council.

${ }^{12}$ As Crowe (p. 38) quoted Skinner, the British feared that "the social and ceremonial aspects of the visit were employed principally to facilitate consultations between the Russian and Turkish military authorities, and to bring about some sort of agreement with respect to the fortification of the Dardanelles. 
Turkey's principle aim, according to De Luca (p. 36) was to secure the militarization, and if not possible, to obtain "a compensating outside guarantee" in the form of an Anglo-Turkish mutual assistance agreement. The British rejection of the remilitarization proposal, this time, was based on the possibility of analogy by Germany for the abolition of the Rhineland zones. However, the British position was to change soon. The general trends in Europe indicated that Britain "might be called upon to honor its commitment" under Article 12 of the Lausanne Convention. In the opinion of the Foreign Office, if Britain might find itself in a position unable "to implement its obligation" the resulting blow to British prestige would be "enormous" (De Luca, p. 38). Therefore, remilitarization seemed a viable alternative.

As early as August 1935, the Foreign Office and the Admirality agreed that "the importance of Turkish friendship far outweigh the disadvantages of complete remilitarization in the Straits". They concluded that it was necessary to maintain friendship with Turkey, since "she might shift over to the German and the Russian camp" (De Luca, p. 40). Britain began to consider Turkey as "a strategic factor in the Eastern Mediterranean lying as it did on the flank of Britain's communications through that sea, and contiguous to Iraq, which Britain was pledged to defend" (De Luca, p. 40). However, they feared that "once Turkey was allowed to resume military control of the Straits all passage in time of war would in practice depend on her good will" (FO 371/ 67286A/ R9068).

The British attitude nevertheless had begun to change. Sterndale Bennet of the Foreign Office, for instance, proposed in a minute written on 29 January 1936, that if Turkey desired to have the Straits question reconsidered, it would be indicated that they should not try to link it with questions not strictly relevant, "but to raise it as a separate issue through the proper channels" (DBFP, Second Series, Vol. XVI, pp. 658-659). On April 4 th, Sir Percy Loraine in his telegram to Eden wrote that the action taken by the Austrian Government in liberating themselves from the military clauses of the treaty of St. Germain would strengthen the elements in Turkey "that might prefer to secure Turkish desiderata by a fait accompli". According to Sir Perey Loraine, these elements would gain further strength if Hungary, and especially Bulgaria, followed the same example. He therefore urged that in order to keep the Turkish Government "on the narrow path of virtue as regards the Straits zones question", it would be better to give "a prompt and favourable response to their request" (DBFP, Second Series, Vol. XVI, pp. 661-662).

Despite the support given on various occasions by the Soviets, Crowe argues that Moscow privately attempted to stall the Turkish effort to obtain revision of the Convention. They found the time for such a move "most inopportune", since it could result in friction between Great Britain 
and the Soviet Union. Fairly reliable sources, according to American officials in Moscow, added that the Sovicts were anxious to postpone any confrontation between the two countries on the Straits question "until the further crystalization of the general European situation" (Crowe, p. 43-44).

On 11 April 1936, the situation in Europe was more or less crystalized, and the time was ripe for the revision of the Straits Convention. Italy and Germany had already proved their aggressive intentions, and the Russians were deeply suspicious of Britain who had concluded a naval arms control agreement with Germany on June 18, 1935. Always complaining about the ingress rights to the Black Sea due to a possible hostile coalition of fleets, the Soviets immediately supported the Turkish note. The British were trying to reestablish their position in the Levant due to the new balance of power in the Mediterranean after the Italian success in Abyssinia. French diplomacy, after the conclusion of the Franco-Soviet Pact of 2 May 1935, desired to increase Soviet influence in the Mediterranean.

There were also some rumours on the possibility of unilateral Turkish action for the fortification of the Straits in 1936 as in 1933. A Reuters dispatch stated that the Turkish Council of Ministers had met on April 15th and decided to occupy the Straits zone militarily. Indeed, Aras also confirmed on April 18th that "Turkey would have to take action to safeguard her position in the Straits area and thereby ensure the security of her national territory", and he thought that "it might be a matter of days and hours before she found it necessary to do so" (DBFP, Second Series, Vol. XVI, p. 663). ${ }^{13}$ Moreover, the British were convinced that "the main desideratum of

${ }^{13}$ Despite the Great Powers willingness, it proved to be more difficult for the Turks to convince some of their immediate neigbours. Rumanians, for instance, feared that a modification of the Straits régime might provoke Bulgaria and Hungary into secking territorial revisions. De Luca contends that one of the principal reasons for Turkey not choosing Article 19 of the League Covenant was related to the desire to avoid arousing the suspicions of the status quo powers in the Balkans. Numan Menemencioğlu, SecretaryGeneral of the Turkish Foreign Ministry, eliminated the Rumanian fears by taking a tour to Bucharest. Rumania, then, declared that it intended to attend the conference "under conditions stipulating that the outcome in no way set a precedent for frontier revisions and thus jeopardise its territorial integrity". Replies continued to reflect national concerns. The Bulgarians, for instance, were to criticise "the clumsy Austrian action" in contrast to the methods chosen by Turkey (De Luca, p. 71). Bulgarian criticism was related to the Austrian unilateral action of introducing conscription in violation of the Treaty of Saint Germain. However, the Foreign Office in Britain suspected that Bulgaria, despite Sofia's cooperative attitude, might seek compensation in the form of an outlet to the Aegean (see De Luca, pp. 67-72). The Italians, on the other hand, refused to commit themselves to the proposed conference. Routh (p. 611) argued that Italian refusal was 
the Turkish Government was to obtain the right to refortify the Straits" (FO 371/ 20086/ E5084). They were given assurances by Aras and Menemencioğlu to the effect that no more demands would be placed into the agenda. $^{14}$

\section{Anglo-Soviet Contention at the Conference:}

On Junc 22 the Conference convened in the Salles des Fetes of the Montreux Palace Hotel with the participation of delegates from Australia, Bulgaria, France, Great Britain, Greece, Japan, Rumania, the Soviet Union, Turkey, and Yugoslavia. The first sessions of the conference were devoted to the reading of the Turkish draft treaty and to the discussions related to it. The preamble of the Turkish draft expressed the desire of the Turkish Government to "regulate the passage and navigation of the Straits in such a way as to safeguard international commerce within the framework of the security of Turkey (sce Montreux Boğazlar Konferansı, 1976: 437).

Despite some minor details regulating commercial traffic, the main divergence of the Turkish proposal from the Lausanne Convention was in Section 2 which dealt with the warships. Tonnage, passage, and types of ships were to be regulated. The maximum force permitted to pass at any one time in peace was to be limited to 14.000 tons, and this limit would be increased to 25.000 ) tons for the littoral states under certain conditions. When Turkey is neutral in a would-be war, the same conditions would apply as in peace time (Article 7 of the Turkish draft), subject to the condition that no warship was to be permitted to commit any act of hostility within the Straits zonc. When Turkey is belligerent, no warships of any Power might pass the Straits without obtaining special permission from Turkey (Article 8). It was also added in Article 9 that in a general or a special threat of war, Turkey could close the Straits as was stipulated in Article 8. This article differed from the same article of the Lausanne Convention only with respect to discretionary rights of Turkey. The Turks were willing to communicate their decision to close the Straits to the League. But they were not so inclined to wait for the League's definition of imminent threat of war (Montreux Boğazlar Konferansı, pp. 441-454).

related to the concern to "keep) in hand a valuable bargaining weapon for abrogation of sanctions and of Mediterranean naval arrangements and even perhaps the recognition of her unilaterally proclaimed empire in Ethiopia".

14 The British had placed rather remarkable emphasis on the Turkish assurances. See F() 371/ 20074/ E2734; E2928; E2988; E3064; E3065. They had even made public the Turkish assurances in their reply to the Secretary of the League of Nations on April 16, 1936. See FO 371/20073/ E2212 and Daily Worker, 21 April 1936. 
The Turkish draft satisfied neither the British nor the Soviets. The British found that it was pro-Soviet, and the Soviets complained that it did not pay necessary attention to Soviet interests. Despite the fact that Litvinov had praised the Turkish draft in the first session of the Conference, he began to impose amendments to the draft at the fourth session (see Montreux Boğazlar Konferansı, pp. 59-72). Thus, the Conference became a duel between the Soviet and British delegations. ${ }^{15}$ Against the British demand for a more liberal régime, Litvinov reiterated the Soviet thesis that a distinction between littoral and nonlittoral powers must be made and ingress rights of the nonlitoral powers should be limited to maximum of 14.000 tons. He demanded that the ingress of submarines and of aircraft carriers of the nonlittoral powers should be prohibited. He also stated his country's desire to add a provision which would allow the honouring of mutual defence pacts with a veiled reference to the Franco-Soviet Pact of 1935.

Lord Stanhope, the chief British delegate, objected to the Soviet demands and stated that the Lausanne Convention had already provided the security the Soviets were seeking at Montreux. As expected, the Soviet position was strongly supported by France and the Little Entente countries, and the role to be played by Britain became crucial for the fate on the Conference (Montreux ve Savaş Öncesi Yılları, p. 69). As Routh (p. 620 ) claimed, Britain cold have taken the opportunity offered by the Conference to unite with France, the Soviet Union, the Balkan and the Little Entente countries against the increased Italian menace in the Mediterranean. But it became perfectly clear during the Conference that this was not her intention. Instead, she chose to return to her early nineteenth century policy of close collaboration with Turkey to stop the Soviet incursion into the Mediterrancan.

This was partly due to her anxiety to avoid dividing Europe into two camps and partly due to mistrust felt for the future intentions of a rapidly arming Soviet Russia. On the other hand, Italy's strength in the Levant, since the conquest of Abyssinia, was increasing. In order to secure their communications with India and their oil supplies from Iraq, the British were compelled to search for new friends in the region. Turkey was the best candidate. As Aras told Sir Percy Loraine on April 24, 1936, "a challenge to British power in the Mediterranean (was) a threat to Turkey's security" (FO 371/ 20073/ E2258).

Another reason for British resistance to the modification of the Straits régime in a more favuorable fashion to the Soviet Union was due to the Anglo-German Naval Agreement signed in July 1935 "which was known to

${ }^{15}$ For a brief overview of the Anglo-Soviet debate at Mortreux see FO 371/ 20080/E5074 and E4633. 
be regarded as a highly satisfactory instrument by the British Admiralty" (Routh, p. 621). With this agreement Germany had consented that the German naval force should not exceed thirty-five percent of British naval strength at any one time. But the escape clause put into the agreement caused trouble. It provided that if the general equilibrium of naval armaments should be violently upset by abnormal and exceptional building on the part of some third Power, the German Government reserve the right to invite H.M. Government of the United Kingdom to examine the new stituation thus created". (Quoted from Routh, p. 621).

At the end of June, rumours were heard in the Western capitals that the German Government intended to invoke the escape clause. In an article published in the Deutsche Diplomatische Korrespondenz (No. 140) the Germans had alleged that Britain had conceded to Russia the right of unrestricted passage for her Black Sca Flect through the Straits. The Foreign Office in London was annoyed with the claims and especially with the last sentence, "which could only be taken to mean that Germany would possibly make the above mentioned observations an occasion for demanding an alteration in the ratio figures laid down in the German-British Naval Agrecments" (I)(GFP, Scries C, Vol. V, 1966: 732). On July 6, the German Charge d'Affairs Bismarck was called to the Foreign Office and Under Secretary of Statc Craige on instructions from Eden informed Bismarck that "the British Government profoundly deplored this German attitude" (DGFP, Series C, Vol. V, p. 732). The British Government then feared that the terms of the Turkish draft and the proposed amendments by Litvinov could provoke the Germans. This, in turn, would put an end to all hopes of concluding a tripartite Anglo-German-Russian agreement on the limitation of naval arms (sec FO 371/ 20(078/ E4457).

Anticipating the impending German reaction, the British vigorously resisted the Sovict thesis which in effect would allow the Soviet fleet entrance into the Mediterranean while denying non-Black Sea powers access to the Black Sca. The first phase of the Conference was closed with the decision to let the Technical Committee work on the Turkish draft on June 25. During the Committee work, the British suddenly presented a new draft on July 4 . The British representative, basing his arguments on the similarity of the two drafts, claimed that the British draft was prepared under the light of discussions between the parties to the Convention both in Montreux and Gencva (Montreux Boğazlar Konferansı, p. 87).

The British draft was, indeed, based on the results of the private discussions that took place in Geneva. As Aras wrote to Ankara on June 28, the British were satisfied with the Turkish guarantees and that, contrary to their carlicr stance, they had shown signs of compromise concerning Soviet egress rights. But the Soviets became more adamant in their attitude. Like the public demands uttered in Izvestia and Pravda, Litvinov in Geneva 
demanded unhindered transfer of the Soviet fleet from one sea to another without paying any attention to Turkish security concerns on July 2 (sec Crowe, p. 69; Montreux ve Savaş Öncesi Yılları, p. 82).

Prime Minister Inönü in Ankara found the Soviet demands "incredible" and instructed Aras to persist with his objections. He even wrote that "if they take the responsibility of infringing the friendship, we won't be without precautions". ${ }^{16}$ Despite the political strains, the Turkish press was conciliatory. Yunus Nadi in Cumhuriyet, for instance, claimed that the Russian objection to the Turkish draft was "unjustified". He wrote that Pravda was misinformed about the tonnage limitations proposed at Montreux. He also maintained that Turkey was directed by her own security requirements (Cumhuriyet, 3 July 1936). The next day an editorial in the semi-official Ulus tried to play down the differences and emphasized the two countries' need for more cooperation. The conciliatory tone of the Turkish press could not conceal the growing rift between Turkey and the Sovict Union. The diplomats began to report the unexpected results of the Montreux Convention as "producing an apparent weakening of 'Turko-Sovict relations" (see Crowe, pp. 73-75).

The Soviet displeasure was increased with the presentation of the new British draft. Litvinov, after protesting the sudden shift, demanded to use both drafts concurrently (Montreux Boğazlar Konferansı, p. 88). Ankara was also irked about the presentation of the new draft. Inönü thought that the new project was completely contrary to Russian interests. The Turks would not support that. Some of the articles were contrary to the Turkish interests too. He had instructed the Anatolian Agency to condemn the proposal publicly. Aras, on the other hand, had already accepted the British proposal as the basis of the discussions and was busy explaining his reasons to Ankara (sec Montreux ve Savaş Öncesi Yılları, p. 94).

The discussions continued with the types and weights of the warships and with the notification procedures for the passage of warships. The key question of the Conference was taken up on July 8. Aras reported that the dispute on Article 16th of the British draft was extremely difficult to settle (Montreux ve Savaş Öncesi Yılları, p. 95). Article 16 demanded that belligerent rights of the belligerent powers be protected in a war in which Turkey should be neutral (sec Montreux Boğazlar Sözleşmesi, pp. 449-450; Routh, p. 629). Litvinov strongly opposed this article and repeated his claim that his country's position required special treatment. He also argued that the Kellogg-Briand Pact had put an end to the doctrine of belligerent rights.

${ }^{16}$ See Montreux ve Savaş Öncesi Yılları (p. 85) and also Gürün (1991: 150). 
In order to meet the Soviet objections, the British proposed an amendment on July 8 . But the amendment was far from satisfying the Soviet demands. Litvinov was opposed to the idea of sole Turkish discretion. He claimed that the League of Nations had to be empowered with the right to decide to close the Straits. France supported the Soviet position. They both thought that the Franco-Soviet Pact could be inapplicable. Litvinov, as a counter proposal, demanded the closure of the Straits to all warships except to those which would fulfil the conditions of a mutual defense treaty if Turkey declared the existence of an imminent threat. Due to the difficulty of reaching a compromise, further discussions were postponed to a later date, and the Conference convened the next day to discuss the Articles 17-21 of the British draft.

These discussions revealed that the British had indeed readopted their 19 th century policy of close collaboration with Turkey. Their proposals and amendments had implied more rights to the Turks than originally intended by the Turks. Since these rights were seen more like duties by Ankara, Aras in Montreux had equivocally told the conference that "Turkey was willing to assume the obligations of the English drafi proposal if it had been accepted, but they were inclined to support the Soviet proposal" (Montreux Boğazlar Sözleşmesi, p. 138). After some hesitation, the Turks tactfully decided to support the British position. They thought that the British proposals would give more room for maneuver. During the discussions on Article 23, Aras expressed his explicit support for the British thesis.

The final compromise was reached on July 15 , the final draft of the Montreux Convention received the unanimous approval of the delegates on July 18 , and several principal changes were accepted by the signatories of the Convention. ${ }^{17}$ First of all, the functions of the international commission were transferred to the Turkish Government, and Turkey, according to the attached protocol, was empowered to refortify the Straits immediately after the signature of the Convention. On the same day at midnight, thirtythousand Turkish troops marched into the demilitarized zone of the Straits (Cumhuriyet, 21 July 1936).

\section{The Results of the Conference:}

With the Convention, Turkey was not only given a greater discretion in the use of its control over the Straits than she had enjoyed since the beginning of the nineteenth century, but she was also provided with a valuable geopolitical asset to be employed in the following decade. From now on the most fragile strategic equilibrium between the Black Sea and

${ }^{17}$ But the actual ceremony was postponed until Titulescu, the chief Rumanian delegate, returned from Bucharest on the 20th. 
Mediterranean powers was in the hands of the Turks. The very existence of mutual assistance pacts tended to underline Turkey's right to take part in these arrangements. Aras, in his speech to the Turkish Grand National Assembly, announced this by emphasizing the importance of Article 19 which stated the conditions for the navigation of warships in the case of Turkey's treaty obligations. ${ }^{18}$ It was stipulated in the Article that

"Vessels of war belonging to belligerent Powers shall not, however, pass through the Straits except in cases arising out of the application of Article 25 of the present Convention, and in cases of assistance rendered to a State victim of aggression in virtue of a treaty of mutual assistance binding Turkey, concluded within the framework of the Covenant of the League of Nations, and registered and published in accordance with the provisions of Article 18 of the Covenant."19

The exceptions to the passage of warships of belligerent powers were made and it was stated that "vessels of war belonging to the belligerent powers whether they are Black Sea Powers or not, which have become separated from their bases, may return thereto."

In the same manner, Articles 20 and 21 left the passage of warships almost entirely to Turkey's discretion, if Turkey was at war, or considered herself threatened by danger of war. More specifically Article 20 stated that "In time of war, Turkey being belligerent, the provision of Articles 10 to 18 shall not be applicable; the passage of warships shall be left entirely to the discretion of the Turkish Government." 20

Turkey's interests were more clearly observed in Article 21 which claimed that

${ }^{18} \mathrm{It}$ is remarkable that Foreign Minister Aras in his speech to the Grand National Assembly had only mentioned Article 19 when he was celebrating the diplomatic victory with the Assembly in July 31, 1936. See T.B.M.M. Zabit Ceridesi, Vol. 12.

${ }^{19}$ Article 25 stated that "Nothing in the present Convention shall prejudice the rights and obligations of Turkey, or of any of the other High Contracting Parties, members of the League of Nations, arising out of the Covenant of the League of Nations.

${ }^{20}$ Article 10 of the Convention dealt with the allowed category of warships, while Article 18 with their aggregate tonnage. For the complete text of the Convention see among others Vali (pp. 200-223); Montreux Boğazlar Konferansı (pp. 479-525); Soysal (1983, Vol. 1: 501-518). 
"Should Turkey consider herself to be threatened with imminent danger of war she shall have the right to apply the provisions of Article 20 of the present Convention.

"Vessels which have passed through the Straits before Turkey has made use of the powers conferred upon her by the preceding paragraph, and which thus find themselves separated from their bases, may return thereto. It is, however, understood that Turkey may deny this right to vessels of war belonging to the State whose attitude has given rise to the application of the present Article.

"Should the Turkish Government make use of the powers conferred by the first pragraph of the present Article, a notification to that effect shall be addressed to the High Contracting Parties and to the Secretery-General of the League of Nations.

"If the Council of the League of Nations decide by a majority of two-thirds that the measures thus taken by Turkey are not justified, and if such should also be the opinion of the majority of the High Contracting Parties signatories to the present Convention, the Turkish Government undertakes to discontinue the measures in question as also any measures which may have been taken under Article 6 of the present Convention."

Articles 19, 20 and 21 composed the core of the Montreux Convention. It was basically because of these three articles that Turkey's impact on European balance of power would be increased. However, among these three, the most delicate one for both Turkey and for the rest of the international community was Article 19. With this article at her disposition, Turkey could easily forfeit her neutrality and grant rights of passage to one set of powers. But any practical value of Article 19 lay with mutual assistance pacts to be signed by Turkey, because there was no provision as to the guarantees to Turkey and the responsibility of decision was solely on Turkey.

Turkey had also obtained some strategic advantages due to changes in the ingress and egress rights. In time of peace the aggregate tonnage of nonBlack Sca Powers in the Black Sea should not exceed 30,000 tons, except by virtue of an escalator clause under which, after increases in the tonnage of the largest Black Sea Fleet, it might rise to a maximum of 45,000 tons. These forces, furthermore, could include nothing larger than "light surface craft". However, there was a remote possibility that, through the permitted use of naval vessels for humanitarian purposes, the above totals of non-riverain tonnage might rise to 38,000 and 53,000 respectively. 
Non-belligerent Black Sea Powers on the other hand, retained the right to send through the Straits ships of any tonnage and without restriction of number, with the provision that vessels of more than 15,000 tons must make the passage individually. Belligerent passage through the Straits during a war in which Turkey was neutral was no longer permissible, except in execution of obligations arising from the Covenant of the League of Nations, or in rendering assistance to a State victim of aggression in virtue of a treaty of mutual assistance binding Turkey, concluded within the framework of the League Covenant. The right of passage was withdrawn from military aircraft and from submarines. Black Sea Powers, however, were to be permitted to bring through the Straits submarines out of the Black Sea for repairs.

Despite the advantages obtained by the Soviet Union, the most clear cut victor of the Convention was Turkey. The new Convention affirmed Turkey's complete sovereignty over the Straits and increased its prestige. The fortifications of the Straits would put Turkey into a more important position in international relations. Turkey was now in a better position to pursue its centuries old policy of balancing the Great Powers' interests against each other. The Great Powers would be willing competitors to curry Turkey's favour. Moreover, the Turks would be able to diminish their dependence on the Soviets without at the same time jeopardizing their security vis-à-vis Italy. They would be able to enhance their security and solve another remaining problem of the Lausanne Convention, that is to say the Hatay question.

\section{Geopolitical Assessments of the Great Powers:}

Soon after the signature of the Convention, the British and Germans admitted that the principal beneficiary of the new régime was Turkey. The Foreign Office claimed that "once the Straits were fortified they would, in existing conditions, be more or less invulnerable against attack from the sea" (FO 371/ 67286A/ R9068). ${ }^{21}$ They added that "the effects of the Montreux Convention would be largely determined by the foreign policy of the Turkish Republic".

Similarly, Keller, the German Ambassador in Turkey, argued that more important than the compromises reached at the Conference were "the

${ }^{21}$ In order to render control of the Straits more effective, the Turkish Government announced a special increase in the military expenditures and the government made a contract with an English firm, Brasset \& Co. for the fortification of the Straits, despite the earlier rumours in 1936 that the said contract had been obtained by the German firm of Krupp. See Routh (p. 645 ) and for the views of the British Ambassador to Moscow concerning Soviet suspicions of these moves see Crowe (p. 74). 
resultant political repercussions with regard to the distribution of power and the tendencies towards the formation of blocs". He added that

"From now on, international policy must, in theory, take into account a Turkey who, strongly fortified at one of her gates of entry and that the most coveted one can, in view of the local conditions there, on the one hand defy any attack, and, on the other, serve as the point of departure for military actions- also in favour of possible allies. The moment from which this situation may in practice be regarded as having come into existance and as forming a factor in strategic calculations, depends on the speed with which Turkey is able to carry out the fortifications of the Straits." (DGFP, Series C, Vol. V, 1966: 834-835).

Moreover, with respect to relations with the Soviet Union, Keller commented:

"If it was Turkey's hope to emerge, by the fortification of the Dardanelles, from her previous role of the weaker partner (a role forced upon her in her treaty relationship with Russia), then she has to a large extent succeeded in doing so, despite the advantages which the Sovict Union enjoys under the new Convention."

The control of the Straits would make Turkey's friendship with nonlittoral powers mandatory and almost virtually essential to littoral powers in time of war. As Keller stated, Turkey could also counterbalance any fluctuations in Moscow's good humour, since she had at her disposal her relationship with Britain.

Turkey's geopolitical importance was soon to be witnessed. The Turks would show that they are one of the important determinants of the strategic equilibrium between the Black Sea and the Mediterranean Powers. The Great Powers should pay due care to Turkey's engagements and decisions. Since these decisions could have significant influence not only on Turkish security but on the European balance of power as well.

The Soviets were aware that the nature of the relations between Ankara and Moscow would either enhance or depreciate their security. If relations between them were to become strained, Turkey could decide to join the Axis powers. The Soviet Union depended on a friendly Turkey for the security of its southern underbelly. The remedy was lying in Article 19 of the Convention which stated that the Straits could be closed to all warships secking to enter the Black Sea, if Turkey were a member of a mutual defence pact with the Soviet Union. Even before the signature of the Convention, Moscow sought to attain a bilateral pact with Ankara. 
The first attempt was as early as June 1936. During their bilateral talks in Montreux on June 22, Litvinow asked Aras his opinion on possible Turco-Soviet joint measures for the defence of the Straits. When Aras transmitted this proposal to Ankara, the Turkish Government found it difficult to understand the nature of the Soviet attempt and could only instruct Aras to unravel the Russian proposal. Aras, according to his instructions, met Litvinov to find out the content of the proposal. To his bewilderment, he was shown a telegraph from Karahan, the Soviet Ambassador in Ankara, that Aras himself had proposed the joint defence of the Straits. Aras, by trying to find out the evidence for the misunderstanding, ostensibly concluded the discussion as was demanded by Ankara (see Montreux ve Savaş Öncesi Yılları, pp. 72-73). ${ }^{22}$

The same subject rose again during his talks with Titulescu, the Romanian Foreign Minister, on June 25. He envisioned a Black-Sea Pact among the littoral powers (Montreux ve Savaş Öncesi Yılları,p. 131). ${ }^{23}$ This was the first occasion which presented to the Turkish diplomats an unprecedented opportunity to utilize their newly gained geopolitical asset. Aras, by realising this opportunity, instructed Zekai Apaydın, the Turkish Ambassador in Moscow, to explore the possibility of the Soviets transferring a marine force to the Mediterranean in the case of an Italian attack on Turkey (Montreux ve Savaş Öncesi Yılları, p. 134).

After failing to get any answer from the Soviets in Moscow, Aras took up the issue in Geneva during his talks with Litvinov in early October. Aras found out that Litvinov was willing to guarantee Turkish security in return for the Turkish guarantee of Romanian security against a German attack. Aras, in order to refrain from sending forces to Romania and thus to further endanger Turkey's security, proposed to assist the Soviets by hindering the German ingress to the Black Sca (Montreux ve Savaş Öncesi Yılları, p. 136).

In the meantime he informed Eden in Geneva about his proposal to Litvinov. As he reported to Ankara, Eden was "deeply interested". But he abstained from giving any concrete reply to Aras. Aras was told that the British reply would be forthcoming and Lord Cranborn, the Parliamentary Undersecretary, would tell him the official British reaction (Montreux ve

${ }^{22}$ By reviewing the inconsistencies of the correspondence between Aras and Ankara, Kamuran Gürün concluded that Aras was trying to push Ankara toward accepting a pact with the Soviets.

${ }^{23}$ Aras told Rendel of the British Foreign Office on June 29 that "Titulescu was strongly pressing him to conclude some kind of Black Sea Pact for mutual assistance". But Aras assured Rendel that "he could not consider anything of this kind". See FO 371/ 20076/ E4082. 
Savaş Öncesi Yılları, p. 138; see also FO 371/ 20094/ E6231). However, the British had already learned of Aras' attempts "from a reliable, but most secret source" as early as August 20 (FO 371/ 20094/ E52880). They thought that the pact proposed by Aras would be similar to Hünkâr Iskelesi (see FO 371/ 20094/ E4871). The British Foreign Office was in the opinion of discouraging such a proposal as soon as possible. In a minute prepared by Rendel on October 5 , the proposal was seen as "throughly objectionable". Rendel argued: "We have already had great difficulty with the Germans over the amount of power of discrimination which has been allowed to Turkey under Article 19 of the Montreux Convention" (FO 371/ 20094/ E6231).

Again on October 8, Rendel commented:

"... if the proposal is of sufficient interest to Russia to justify Russia offering to guarantee Turkey against any attack in the Mediterranean. Its political implications are obviously important; and its results would in fact be a virtual Russo-Turkish Alliance... My own impression is that this is a personal brainwave of M. Aras. M. Aras is much under the personal influence of M. Litvinov." (FO 371/ 20094/ E6231).

Aras explained to Lord Cranborn on October 13 that his discussion with Litvinov "represented no additional commitment for Turkey" (FO 371/ 20094/ E6467). But the British constantly feared that Aras might seek "some way of giving the Soviet Government some satisfaction" and satisfying the Soviets did not please them (see FO 371/ 20094/ E7236). The British had to maintain the delicate balance both in political and naval matters. They tried to preserve the status quo in the Continent, while trying to maintain the naval balance with Germany. The Foreign Office concluded that

"Attempt(s) by Russia to assume (sic.) more important role in Mediterranean would be quite natural in view of Russia's increasing interest in Spain where she may possibly hope at least to secure establishment of independent Soviet Republic in Catalonia under virtual Russian control. Moreover, Mediterranean outlet is likely to become increasingly important to Russia if only in view of growing German danger to Baltic ports." (FO 371/ 20094/E6768).

However, the Soviets could only play an effective role in the Mediterranean if they secured the "subservience of Turkey". The Foreign Office thought that Russia could "therefore be playing on Turkey's fear of Italy in the hope of eventually manoveuring Turkey into a position of political dependence on her". Such a development would be "objectionable from point of view of His Majesty's Government and of European policy generally, since the genuine independence of Turkey constitutes a useful 
stabilizing factor" (FO 371/20094/ E6768). Therefore, it was in the British interest to prevent Turkey from concluding such a pact. A Franco-Soviet collaboration with Turkey might, not only jeopardise the future of the 1935 Naval Agreement between Germany and Britain, but it could at the same time widen the existing gap between these powers and Germany.

Indeed, the Germans had already been disturbed about the detente between Britain and the Soviet Union produced as a result of concessions given to the Soviet Union by Britain. The German press had criticised "the fickleness of the British policy" (Routh, p. 47). Moreover, these developments might push Italy towards Germany.

The Germans were not reluctant to show their concerns. On October 7, the German Chargé d'affaires in London, Prince Bismarck, talked with Craigie on matters concerning the effects of the Montreux Convention. Bismarck gave the examples that the German strategic position had deteriorated at sea after the fortifications. Craigie, for his part claimed that the German representation was not justified as long as Turkey did not formally enter into a pact of mutual assistance with the Soviet Union. But this was not the case at the present, Craigie continued, and assured Bismarck that "Turkey would not conclude such a pact with Russia" (DGFP, Vol. V, p. 954).

The British Foreign Office tried to belittle the effects of the Convention in the following weeks. Craigie asked Bismarck to call at the Foreign Office to discuss the British Government view point with respect to the Convention on October 28. Bismarck and Wocrman, the newly appointed Counsellor of the German Embassy in London, was handed a memorandum when they went to the Foreign Office. However, Woerner believed that the Foreign Office attached importance to handing them the answer "before the resumption of the discussions on the naval question with the object of demolishing one of the arguments which (Germans) had employed in the naval negotiations" (DGFP, Series C, Vol. V, pp. 1152-1156). The aidemémoire specified that

"His Majesty's Government cannot accept the assumption that appears to underlie Prince Von Bismarck's statement, namely that, if Turkey remains in as close relation with Soviet Russia as she is today, she cannot be expected to carry out impartially her obligations under the Montreux Convention. On the contrary, it is at least equally legitimate to surmise that, once the Straits have been remilitarised, Turkey will acquire a sense of strength and independence which will free her from the necessity of assuming commitments which might conceivably be held to conflict with her existing obligations under the Covenant." 
The aide-memoire was concluded with the hope that the German Government "will be prepared to agree that the strategic effects of Montreux Convention are likely to be of less consequence than they had first anticipated" (DGFP, Vol. V, p. 1156). However, Craigie, just a few weeks before, had written that

"On first impression, I see some cause for uneasiness should this proposal materialize. Moreover, if it should subsequently become known that we had consented in advance, as it probably would, the effect upon Italy and possibly Germany also, might be most unfortunate... This is to my mind a serious development. However plausibly M. Aras may present the proposal, it amounts to a RussiaTurkish alliance, and will certainly be regarded as such to Germany, Italy and Japan. It will be a further step in the alignment of the world into two hostile camps, which seems to be the principal aim of $\mathrm{M}$. Litvinov's foreign policy" (Quoted from Crowe, p. 119).

Craigie concluded that the present naval ratios would not be acceptable to Berlin, if Turkey was controlled by Moscow. Thus, "if this absurd Turkish proposal goes through, Russian influence will again become paramount at Angora, and our own will diminish proportionate(ly)" (FO 371/ 20094/ E6231). Craigic's advisers in Whitehall were equally disturbed by the developments and they claimed that such a pact would make "Turkey an accessory to the Franco-Soviet Pact" (Crowe, p. 120). Moreover, Italy would also not welcome "the thought of a Soviet fleet sailing into the Mediterranean to protect Turkey" (Crowe, p. 121). "The proposed arrangement would militate against the conclusion of a Mediterranean Pact" and hinder "bringing about real appeasement in the Mediterranean" (F.O. 371/ 20094/E6231). 24 The same view had also been explained to Fethi Okyar, the Turkish Ambassador in London, and it was added that the proposed Soviet guarantec to Turkey would be extremely dangerous since it would amount to "something very like a Russo-Turkish alliance" and it would further complicate the Mediterranean situation (F.O. 371/ 20094/ E3499; see also Gürün, p. 162).

The new Convention had also aroused suspicions in the German Foreign Ministry from another angle. Keller noted that the inclusion of paragraph 2 in Article 19, despite the earlier resistance by Britain, showed the

${ }^{24}$ The Italians were disturbed from Turko-Soviet reconciliation. An article in the Osservatore Romano, published on 8 October 1936, claimed that "Turkey's gain was also Russian gain. The importance of this lay in the fact that with Nazi Germany jealously watching the Baltic, with Poland defending the heart of Europe, and with Italy, Germany and Yugoslavia guarding the Danube basin the only remaining outlet for the Bolshevism towards the West was through the Straits". See FO 371/ 20094/ E6440. 
British confidence that Turkey would make "wise use of this liberty". When Keller asked the Turkish acting Foreign Minister, Saracoğlu, about the possibility of a pact between Britain and Turkey, he got the impression that efforts were "in fact being made to draw Turkey into treaty relations of this kind, but that she will not lightly surrender her freedom of choice" (DGFP, Series C, Vol. V, p. 832).

By the end of October, the Turkish Government had decided not to proceed further with Aras's project. Besides British diplomatic pressures, Ankara was wary of the possibility that they could undertake commitments which they might not fulfil and paralyze economic life without taking any precautionary measures (Montreux ve Savaş Öncesi Yılları, p. 137). This move, nevertheless, can be considered as the first reminder to the international community that they should consider Turkey as an important factor in their strategic calculations.

\section{Conclusion:}

As stated in the introduction, Turkey is one of those small states which hamper, or at least bar, the extension of the influence of a great power into the sphere of interest of another great power. Even its continued existence in the last few hundred years was to a grcat extent due to the fact that great powers wanted territory occupicd by this weak state rather than by a dangerous rival. As long as its integrity served to the benefit of British strategy, Russian desire to hasten the dismemberment of the Ottoman Empire was countered by Britain. Until the emergence of Germany as a Great Power, Turkey was able to play Russia against Britain, largely due to their conflicting interests in the Straits.

Possession of this territory by the Turks guarantced the prohibition of non-Turkish warships in the Straits. This was regarded as satisfactory by Britain until the late nineteenth century. Then the Russians demanded unilateral rights of egress for their warships. This was seriously considered by the British at the beginning of this century due to the desire to appease the Russians against the increasing German threat. At that time the Turks lost their most important geopolitical asset for their dealings with these two great powers. In 1915, the French and British Governments agreed to the annexation by Russia of the shores of the Straits. Despite the drift between Anglo-Russian relations after the 1917 Revolution, the Straits régime established at Lausanne enabled the British directly to control the waterway. British control deprived the Turks for over 13 years of their most important geopolitical asset. It was only with the signature of the Montreux Convention, under the impact of the growing tension in the international system preceding the Second World War, that the Turks regained their most important asset. 
This article dealt with the Great Power rivalry over the Straits. But it is also about the strategic advantages and the assets obtained by Turkey at Montreux. Turkey's interests were favoured even more than expected by the Turks themselves. Above all the participants, Turkey found its interests best represented. Articles 19, 20, and 21 made Turkish friendship mandatory for the Great Powers. This gave the Turks a wide room to maneuver. Even without explicitly using these assets in their bargains, they were able to procure all they wanted.

The new Straits régime had indeed added valuable assets to the Turkish geopolitical inventory. As Robertson (1986: XVI) claimed, Turkey in the following years would be able to exercise an influence on international affairs beyond that of a small power with a limited potential. Turkey, by holding a key geographical location and possessing the guardianship of the Straits, made her friendship mandatory for Britain, Germany, and the Soviet Union. It would cash in these assets on several occasions. The Turkish diplomats would solve the remaining problems of the Lausanne Convention, enhance their security and even remain outside the war. Because the new status quo would cause a remarkable concern within the Great Powers, Turkish mancuvers to settle these concerns would lead to unanticipated, if not anticipated results. Turkey would become an important factor in the international power balance and the Convention would become a valuable instrument in the hands of Turkish diplomacy.

However, international conditions drew the limits of the Turkish influcnce attempts. The Abyssinian war was the main factor behind the Anglo-Turkish rapprochement. This war had brought the policies of the two countries into closer accord and had led the British to support the Turkish position in the Montreux Convention. Another Italian attempt in April 1939 would further consolidate Anglo-Turkish interests. Italian invasion of Albania would become the main stimulus behind the Anglo-Turkish declaration in May 1939. The international implications of this declaration far exceeded the guarantees obtained by Turkey. The new Straits régime was the underlying reason for both the guarantees and the international implications.

It is highly likely that the Straits issue will enter the international agenda in the near future. The parties to the Montreux Convention may state their intention to denounce it in 1996. In fact, the Convention was found out-moded long before. By the end of the Second World War the Allies had almost reached a consensus as to the necessity of changing the terms of the Convention. But the emerging international tension and the maneuvers of the Turkish diplomacy had prevented the issue from reaching the appropriate international forum. 
Now, the Cold War between the Great Powers is over, and international tensions which could lead to great power conflicts are largely eliminated. If the Great Powers can resist the temptations of the new challenges emerging throughout the world, they may govern the world with a Great Power strangle-hold. There seems to be a consensus to govern the world in this way. Such a strategy could have adverse repercussions for small states. While providing peace and stability to the world in general, it may lead to subservience of small powers' interests to those of the Great Powers. Besides, in order to maintain the prevailing mood, the Great Powers may become more willing to sacrifice small states' interests.

But what is more interesting is that small states themselves have become more willing to sacrifice their own interests. The prevaling mood should have affected them more than the Great Powers. Even in Turkey, there seems to be an emerging consensus on the desirability of "modifying" the so-called "defunct" Montreux Convention. Several scholars have argued that the Convention was far from giving necessary guarantees to Turkey's newly discovered interests (see Cumhuriyet, 21-22 January 1992). They claim that the Montreux Convention should be revised to include economic and ecological measures. Some even go so far as to suggest that Turkey take the initiative to convene a new conference. But they forget the precarious nature of the Convention. This article most of all should be considered as an attempt to ímply that nature and its effects on Turkish foreign policy.

$$
\text { * } \quad * \quad *
$$

\section{BIBLIOGRAPHY}

\section{Unpublished Documents:}

Foreign Office General Correspondence (FO 371) documents covering the years 1933-1946 are quoted in the text according to their direct access codes in the Public Record Office, Kew Gardens, London.

\section{Official Publications:}

Documents on German Foreign Policy: 1918-1945 (DGFP), London, Her Majesty's Stationary Office.

Documents on British Foreign Policy, 1919-1938, Second Series, Vol. 7 (DBFP) London, H. M. Stationary Office.

Montreux Bogazlar Konferansı: Tutanaklar, Belgeler Ankara, Siyasal Bilgiler Fakültesi Yayınları, 1976.

Montreux ve Savaş Öncesi Yılları Ankara, Dışişleri Bakanlığı. 
TBMM Zabıt Ceridesi.

\section{Newspapers and Periodicals:}

Except Cumhuriyet and the other Turkish dailies which are quoted from Ayın Tarihi; the American, the British and the other dailies such as Osservatore Romano and Izvestia are quoted from the PRO archives.

\section{Secondary Sources:}

Akşin, Sina et. al (1990) Türkiye Tarihi: Osmanlı Devleti, 16001908, Vol. 3, Istanbul, Cem Yayınevi, 1990.

Armaoğlu, Fahir, 20. Yüzyıl Siyasi Tarihi: 1914-1980, Ankara, Iş Bankası Kültür Yayınlan, 1984.

Bıyıkoğlu, Tevfik, Türk Istiklâl Harbi: Mondros Mütarekesi ve Tatbikati, Vol. 1, Ankara, M.S.B. Genelkurmay Başkanlığı Basımevi, 1962.

Crowe, F. Standefer, The Soviet Union and the Turkish Straits, 1933-1945, Ann Arbor, University Microfilms, 1973.

De Luca, Antony R., The Montreux Conference of 1936: A Diplomatic Study of Anglo-Soviet Rivalry at the Turkish Straits, Ann Arbor, University Microfilms, 1973.

Esmer, Ahmet Şükrü, "The Straits: Crux of World Politics", Foreign Affairs, Vol. 25, No. 2 (1947).

Gürün, Kamuran, Türk-Sovyet Ilişkileri (1920-1953), Ankara, Türk Tarih Kurumu Basımevi, 1991.

Inönü, Ismet, Hatıralar, Istanbul, Bilgi Yayınevi, 1987.

Karacan, Ali N., Lozan Konferansları ve İsmet Paşa, Istanbul, Maarif Matbaası, 1943.

Howard, Harry N., The Partition of Turkey, 1913-1923, New York, Ferting, 1966.

Howard, Harry N., Turkey, the Straits and U.S. Policy, London, The John Hopkins University Press, 1974. 
Hurewitz, J.C., Diplomacy in the Near and Middle East: A Documentary Record, 1914-1956, New Jersey, Princeton, 1956.

Israel, Fred L., Major Peace Treaties of Modern History, 16481967, New York, Chelsea House Publishers, 1967.

Kunt, Metin, "Osmanlı Devletinin Barış̧̧ı Siyaseti", in Sina Akşin, Osmanlı Devleti: 1600-1908, Istanbul, Cem Yayınevi, 1990.

Joll, James., Europe Since 1870, Penguin Books, 1978.

Mathisen, Trygve, The Functions of Small States in the Strategies of Great Powers, Oslo, Universitetsforlaget, 1971.

Öke, Mim Kemâl, İngiliz Belgelerinde Lozan Barış Konferansı: 1922-1923, tstanbul, Boğaziçi Üniversitesi Yayınları, 1983.

Olaylarla Türk Dış Politikası, Ankara, Siyasal Bilgiler Fakültesi, 1986.

Robertson, John, Turkey and the Allied Strategy: 1941-1945, London, Garland Publishers, 1986.

Routh, D. A., "The Mediterranean: The Montreux Convention Regarding the Régime of the Black Sea Straits (20th July 1936)", in Amold Toynbee, ed., Survey of International Affairs: 1936, London, Oxford University Press, 1937.

Tukin, Cemal, Osmanlı İmparatorluğu Devrinde Boğazlar Meselesi, Istanbul, Üniversite Matbacılık Komandit Şti., 1947.

Uçarol, Rıfat, "Değişmekte Olan Dünyada Türk Boğazları'nın Önemi ve Geleceği", in Sabahattin Şen, ed., Yeni Dünya Düzeni ve Türkiye, Istanbul, Bağlam Yayınları, 1982.

Vali, Ferenc A., The Turkish Straits and NATO, California, Hoover Institution Press, 1972. 